\title{
Comparison of CD38, ZAP70 and hTERT Expression with Known Prognostic Markers in Patients with Chronic Lymphocytic Leukemia During Five-Year Follow- up Period
}

\author{
Filiz VURAL ${ }^{1}$, Emin KARACA ${ }^{2}$, Nur SOYER ${ }^{1}$, Cumhur GUNDUZ ${ }^{3}$, Fahri SAHIN ${ }^{1}$, Buket KOSOVA ${ }^{3}$, \\ Guray SAYDAM, Seckin CAGIRGAN ${ }^{1}$, Murat TOMBULOGLU ${ }^{1}$, Ferda OZKINAY ${ }^{2}$, Ozgur COGULU ${ }^{2}$
}

\author{
${ }^{1}$ Ege University, Faculty of Medicine, Department of Hematology \\ ${ }^{2}$ Ege University, Faculty of Medicine, Department of Medical Genetics \\ ${ }^{3}$ Ege University, Faculty of Medicine, Department of Medical Biology, Izmir, TURKEY
}

\begin{abstract}
Chronic Lymphocytic Leukemia (CLL) is the most common leukemia in adults. Recently CD38, ZAP70 and hTERT activity have been studied for the evaluation of the prognosis of CLL besides clinical staging and lymphocyte doubling time. There are inconsistent results regarding these markers for the evaluation of the prognosis in CLL patients. In this study CD38, ZAP70 and hTERT values in CLL patients were measured to make comparisons between each other and known prognostic factors. Thirty CLL patients who were included in the study

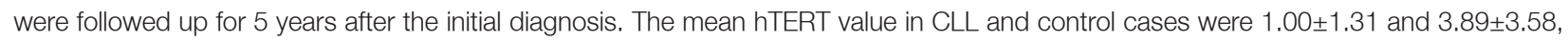
respectively ( $p<0.05)$. The mean CD38 and ZAP70 were 6.20 \pm 7.60 and $5.51 \pm 5.67$, respectively. No significant association was detected between CD38, ZAP70 and hTERT activity. There was no correlation between those parameters and known prognostic parameters such as Rai staging, peripheral lymphocyte levels, age, and sex of the patients, beta-2 microglobulin and reply to treatment in CLL. The overall five-year survival rate in CLL patients is $96.7 \%$. The overall five-year survival rate in CLL patients is $96.7 \%$. In conclusion, further studies including larger series of patients with longer follow-up periods are recommended.
\end{abstract}

Keywords: hTERT, CD38, ZAP70, Chronic Lymphocytic Leukemia

\section{ÖZET}

Kronik Lenfositik Lösemili Hastalarda Bilinen Prognostik Belirteçlerin CD38 ZAP70 ve hTERT Ekspresyonları ile Beş Yıllık Takip Döneminde Karşılaştırılması

Kronik Lenfositik Lösemi (KLL), eriskinlerde en sık görülen lösemidir. KLL hastalarında, son zamanlarda CD38 ZAP70 ve hTERT etkinliğinin değerlendirilmesi ve prognozun yanında evreleme ve lenfosit ikileme zamanı ile iliskisinin belirlenebilmesi için çalısmalar yapılmaktadır. KLL hastalarında prognozun değerlendirilmesi için yapılan çalısmalarda tutarsız sonuçların olduğu görülmektedir. Bu çalısmada KLL hastalarında CD38 ZAP70 ve hTERT değerleri birbirleriyle ve bilinen prognostik faktörler arasında karsılastırma yapılarak değerlendirildi. Çalısmaya dâhil edilen $30 \mathrm{KLL}$ hastası ilk tanıdan sonra 5 yıl boyunca takip edildi. KLL hastaları ve kontrol olguları ortalama hTERT değeri sırasıyla $1.00 \pm 1.31$ ve $3.89 \pm 3.58$ idi ( $p<0.05$ ). Ortalama CD38 ve ZAP70 değerleri sırasılla $6.20 \pm 7.60$ ve $5.51 \pm 5.67$ olarak saptandı. CD38 ZAP70 ve hTERT aktiviteleri arasında anlamlı bir iliski saptanmadı. Bu parametrelerle, Rai evrelemesi, periferik lenfosit değerleri, yas, cinsiyet, beta-2 mikroglobulin (B2M) ve tedaviye cevap gibi bilinen prognostik faktörler arasında istatiksel olarak anlamlı bir fark saptanmadı. KLL hastalarında 5 yıllık ortalama sağ kalım süresi \%96.7 olarak saptandı. Daha büyük, takip süreleri daha uzun hasta grupları ile ileri çalısmaların yapılmasının uygun olacağı düsünülmüstür.

Anahtar Sözcükler: hTERT, CD38, ZAP70, Kronik Lenfositik Lösemi 


\section{INTRODUCTION}

Chronic lymphocytic leukemia (CLL) is the most common leukemia in adults which comprises approximately $16-30 \%$ of all leukemia cases. ${ }^{1}$ It is more common in males and mostly occur after the age of 60 years. ${ }^{2,3}$ Disease progress is quiet variable according to a number of factors. Life expectancy may be greater than 10 years in most patients with early stage; however patients with more advanced stage have a median survival of 18 months to 3 years. ${ }^{4}$ The Rai and the Binet systems are two commonly accepted staging methods in CLL., ${ }^{5,6}$ The prognosis is related to the particular biological parameters such as cytogenetic abnormalities, mutational status of $\operatorname{IgVH}, \mathrm{VH} 3.21$ usage, expression of ZAP70 and CD38, serum markers $\mathrm{CD} 23$, thymidine kinase and beta2-microglobulin (B2M), bone marrow examination and lymphocyte doubling time. ${ }^{7}$ Although those markers may help to predict the prognosis, the application of these tests is not suggested to be used in routine practice for the treatment. ${ }^{7}$ There are discrepancies between the usages of those molecular markers and their impact on the prognosis of the disease. Moreover, there is certainly an ongoing question regarding the clinical usefulness of those markers, particularly ZAP70 and CD38. ${ }^{8}$ These several known prognostic markers fail to cover the complex heterogeneity of CLL. Because of this, new markers must be developed to overcome the unknown part of CLL. One of the most promising markers is telomerase activity (hTERT). hTERT messenger RNA (mRNA) expression seems to be the most important and limiting step for telomerase activation and it is related with poor clinical outcome in most cancer types. ${ }^{910}$ Recent studies have focused on the potential prognostic significance of telomerase activity in CLL, in addition for a better established prognostic marker. ${ }^{11-16}$ This study aimed to show the association between the prognosis of CLL and another marker, telomerase activity, in combination with other prognostic parameters. Therefore we investigated hTERT gene expression in 30 chronic lymphocytic leukemia cases and evaluated its prognostic value with CD38 and ZAP70 expression. Their association with known prognostic parameters was also evaluated. All patients were followed up for the following 5 years after the initial diagnosis.

\section{PATIENTS AND METHODS}

\section{Patients}

A total of 30 newly diagnosed CLL patients (male: 14 , female: 16 , median age: 65.00 years) and 10 agematched healthy controls [(male: 4 , female: 6 , median age: 57.00 years) were included into the study. All patients were followed up for 5 years (Table 1). CLL was diagnosed according to accepted clinical, morphological and immunological criteria's and classified by Rai staging. ${ }^{17}$ According to the Rai staging system, Rai Stage 0 is designated as a low risk (expected survival is $>10$ years), Rai Stages I and II are designated as intermediate risk stages (expected survival is 6-8 years), Rai Stages III and IV are designated as high risk stages (expected survival is $<2$ years). It is also accepted as early (Rai stage 0 through II) or late (Rai stage III through IV) which is used in our study. Bone marrow aspiration was performed in all patients. Fourteen patients were treated. Eight patients were treated for progressive lymphocytosis (Doubling time of less than 6 months), 2 for cytopenias and 4 for progressive lymphadenopathy. The ex-

\begin{tabular}{|c|c|c|c|c|}
\hline Patients & $\mathbf{N}$ & Minimum & Maximum & Median \\
\hline Age & 30 & 44 & 84 & 65.00 \\
\hline NhTERT & 30 & 0 & 4.76 & 0.54 \\
\hline CD38 (\%) & 30 & 0.50 & 40 & 4.20 \\
\hline ZAP70 (\%) & 30 & 0.70 & 22.40 & 2.80 \\
\hline Lymphocyte levels & 30 & 11800 & 261200 & 24800 \\
\hline \multirow[t]{2}{*}{ B2M } & 30 & 1572 & 4623 & 24000 \\
\hline & & M & $\mathbf{F}$ & \\
\hline \multirow[t]{2}{*}{ Sex } & 30 & 14 & 16 & \\
\hline & & Early & Late & \\
\hline Stage & 30 & 14 & 16 & \\
\hline
\end{tabular}


pression levels of CD38, ZAP70 and hTERT activity were compared with the age and sex of the patients, staging (Rai), peripheral lymphocyte levels, B2M and reply to the treatment. The study was approved by the ethical review committee of Ege University Medical Faculty. Written informed consent was obtained from the patients and healthy controls.

\section{hTERT mRNA Expression Analysis}

Two $\mathrm{mL}$ of peripheral blood was taken for the hTERT mRNA expression analysis. Blood/Bone Marrow Kit (Roche Applied Science, Mannheim, Germany) was used for total mRNA extraction according to the manufacturer's protocol. The concentration and purity of the RNA samples were checked by the UV absorption at $260 \mathrm{~nm}$ and by the absorption ratio of 260 to 280 $\mathrm{nm}$, respectively. RNA samples were stored at $-86^{\circ} \mathrm{C}$ till gene expression analysis. hTERT mRNA determination was performed with commercially available LightCycler TeloTAGGGG hTERT Quantification Kit (Roche Applied Science) using the LightCycler instrument for real-time PCR. All subsequent quantification steps were carried out according to the manufacturer's instructions. It is specific for hTERT mRNA which encodes active telomerase protein and a housekeeping gene porphobilinogen deaminase (PBGD) mRNA. The hTERT mRNA level was determined as the relative ratio by dividing the level of hTERT mRNA by the PBGD level in the samples [10,000 x (hTERT/PBGD)].

\section{Flow Cytometric Analysis of ZAP70 and CD38 Expression}

Two $\mathrm{mL}$ of peripheral blood was taken for flow cytometric analysis. Frozen mononuclear cells (MNC) were resolved at $37^{\circ} \mathrm{C}$ in Bain-marie and then washed with RPMI-1640 supplemented with cold $10 \%$ fetal calf serum immediately in order to remove dimethyl sulphoxide (DMSO). Dead cells were removed by density gradient centrifugation (Histopaque ${ }^{\circledR}-1077$, Sigma-Aldrich Chemie GmbH). Thereafter, live cells were resuspended in phosphate buffer solution (PBS) containing $2 \%$ fetal bovine serum (FBS). Mouse antihuman CD38-FITC (BD Biosciences) monoclonal antibody was used for cell surface staining. FACS ${ }^{\mathrm{TM}}$ permeabilizing solution 2 (BD Biosciences) was used for fixation and permeabilization. Anti-mouse/human ZAP70- PE (eBioscience) monoclonal antibody was used for intracytoplasmic staining. The analysis was performed with FACScalibur ${ }^{\mathrm{TM}}$ flow cytometry (serial number, E 97501117, BD Biosciences) instrument and CellQuest ${ }^{\mathrm{TM}}$ Pro software (Apple Computer, Inc.). CD38 (+) and ZAP70 (+) expression were recorded as percentage of gated MNCs monitored in CD38-FITC (FL1) versus ZAP70-PE (FL2) dot plot.

\section{Statistical Analysis}

All statistical analyses were performed by using SPSS for windows. Regression analysis was used in the analysis of the associations between the different variables, and one-way ANOVA and Student's t test were used to compare the means. A P value of $<0.05$ was considered statistically significant.

\section{RESULTS}

Of 30 CLL cases, expression of the CD38, ZAP70 and hTERT minimum and maximum levels with median values are shown in table 1 . Twenty-four patients were in early and 6 were in late stages according to the Rai staging. There was no significant correlation between hTERT activity and widely used prognostic factors CD38 and ZAP70 expressions. When the patients were divided into two groups according to the treatment, no significant difference was detected between treated and untreated patients (Table 2). The levels of hTERT, ZAP70, B2M and age at diagnosis were found to be increased with advancing B-CLL Rai stage (Table 2). CD38, ZAP70 and hTERT expression were not correlated with Rai staging and treatment. B2M and lymphocyte count were found to be related with Rai staging (Table 2). Lymphocyte count was correlated with B2M (Pearson Correlation $\mathrm{R}=0.72, \mathrm{p}=0.0001$ ) and hTERT (Pearson Correlation $\mathrm{R}=0.62, \mathrm{p}=0.00094$ ) values (data not shown).

\section{DISCUSSION}

The aim of the present study was to evaluate the association between the prognosis of patients with CLL and the most commonly used biological markers, ZAP70 and CD38. hTERT activity was also evaluated in the study to reveal its prognostic value. All patients were followed up for 5 years after the initial diagnosis. No correlation was detected between the values of ZAP70, CD38, hTERT and almost all parameters used for prognostic factors in CLL. One patient who died because of CLL had very low ZAP70 and CD38 values which were lower than both commonly used 


\begin{tabular}{|c|c|c|c|c|}
\hline & \multicolumn{3}{|c|}{ Treatment } & \multirow[b]{2}{*}{$\mathbf{p}$} \\
\hline & $\begin{array}{l}\text { Treated }(n: 14) \\
\text { Mean } \pm \text { SD }\end{array}$ & $\begin{array}{l}\text { Untreated } \\
\text { (n:16) Mean } \pm S D\end{array}$ & $\begin{array}{l}\text { Total } \\
(\mathbf{n = 3 0}) \text { Mean } \pm S D\end{array}$ & \\
\hline NhTERT & $1.34 \pm 1.60$ & $0.69 \pm 0.94$ & $1.00 \pm 1.31$ & 0.098 \\
\hline CD38 & $3.90 \pm 2.77$ & $8.21 \pm 9.79$ & $6.20 \pm 7.60$ & 0.124 \\
\hline ZAP70 & $4.49 \pm 3.51$ & $6.41 \pm 7.05$ & $5.51 \pm 5.67$ & 0.366 \\
\hline Age & $67.19 \pm 10.62$ & $61.79 \pm 8.80$ & $64.67 \pm 10.02$ & 0.144 \\
\hline Lymphocyte levels & $69061.43 \pm 85171.02$ & $45840.67 \pm 59700.81$ & $57050.69 \pm 72729.08$ & 0.400 \\
\hline \multirow[t]{4}{*}{ B2M } & $2661.92 \pm 903.46$ & $2528.27 \pm 755.99$ & $2598.00 \pm 820.10$ & 0.706 \\
\hline & & Staging & & \\
\hline & Early & Late & Total & \\
\hline & (n:24) & (n:6) & $(n=30)$ & $\mathbf{p}$ \\
\hline NhTERT & $0.94 \pm 1.20$ & $1.19 \pm 1.79$ & $1.00 \pm 1.31$ & 0.804 \\
\hline CD38 & $6.49 \pm 8.33$ & $5.03 \pm 3.72$ & $6.20 \pm 7.60$ & 0.765 \\
\hline ZAP70 & $4.60 \pm 4.41$ & $9.15 \pm 8.80$ & $5.51 \pm 5.67$ & 0.420 \\
\hline Age & $63.08 \pm 10.24$ & $71.00 \pm 6.42$ & $64.67 \pm 10.03$ & 0.221 \\
\hline Lymphocyte levels & $33298.70 \pm 33924.78$ & $148100.00 \pm 109609.74$ & $57050.69 \pm 72729.00$ & 0.000 \\
\hline B2M & $2379.84 \pm 660.57$ & $3634.25 \pm 762.18$ & $2598.00 \pm 820.10$ & 0.003 \\
\hline
\end{tabular}

values in the literature and the mean value of 30 patients in this study.

The most important prognostic factors in CLL have been reported as clinical stage, tumor load markers, both CD38 and ZAP70, and genetic parameters. ${ }^{18,19}$ In the literature cellular proteins ZAP70 and CD38 have been found to be closely related to the prognosis of CLL. ${ }^{20,21}$ While the cut-off value for ZAP70 is $20 \%$, it is $30 \%$ for CD38. However $7 \%$ and $20 \%$ have also been used as cut-off values for CD38. ${ }^{22-26}$ Although ZAP70 has been shown as an independent prognosis parameter in many studies, there are controversies for CD38. ${ }^{27}$ As it has been suggested by Moreno et al. the correlation of IgVH mutations, ZAP70 and CD38 expression with response is unclear and needs further investigation. ${ }^{28}$ Besides many studies which have supported the prognostic significance of those markers, there is considerable number of controversial comments as well. ${ }^{29} \mathrm{We}$ have found median values for ZAP70 and CD38 as 2.80 and 4.20, respectively. The values of those parameters in this study were above widely accepted values in 9 and 3 patients out of 30 patients, respectively and all were alive in the following 5 years follow up period of the study. There are two widely accepted staging systems in CLL: the Rai and the Binet which depend on parameters such as splenomegaly, lymphadenopathy, and the the levels of hemoglobin, platelet and lymphocyte count. Similar to cellular proteins, ZAP70 and CD38, the prognostic impact of those staging systems that has been accepted to be important for survival has controversies as well. It has been stated that there is currently little evidence that clinical stage could be used as a predictive factor in CLL. ${ }^{20}$ Other parameters such as bone marrow infiltration pattern, the lymphocyte doubling time, the serum LDH level have also prognostic relevance in CLL. ${ }^{30}$ We have found a significant correlation only between Rai staging, and B2M and lymphocyte levels. Patients staged in late Rai categories were having higher levels of B2M and lymphocyte levels. When Rai staging system is taken into account, 6 patients in late group whom expected survival is less than 2 years did not have high levels of ZAP70, CD 38 and hTERT. Two speculations can be made with regard to the correlation between those parameters and the prognostic impact in CLL; first our results support the prognostic importance of ZAP70 and CD38, since those values show good prognosis and all but one patient are alive at the end of 5 years follow up. Second Rai staging has to be evaluated in much larger series, since the patients in different staging groups do not correlate with the expected survivals. According to the other parameters which have been evaluated in this study, 
no correlation was detected between the treatment of the patients and all other prognostic factors. Interestingly lymphocyte count was correlated with B2M and hTERT values. Regarding the impact of hTERT values in CLL, many studies have found a worse prognostic effect in cases having higher hTERT values. ${ }^{12,31-34}$ On the other hand very few studies have reported no correlation between the prognosis and hTERT activity as well.16In our study the only correlation regarding the hTERT values was found with the increasing age of the patients. Neither ZAP70 nor CD38 values were correlated with any of those parameters including hTERT.

It should be noted that the limitation of this study is the small number of patients and relatively shorter duration of follow up of those cases. Therefore those correlations may gain significance if larger series of studies are performed.

In conclusion our study revealed that prognostic parameters such as B2M are closely correlated with the Rai staging and no correlation was detected between ZAP70, CD38, hTERT activity and other prognostic parameters. Further studies with larger series will be needed in order to establish the clinical value of those parameters in CLL.

\section{Acknowledgements}

We would like to thank the staff in the Department of Medical Genetics, Medical Biology and Internal Medicine Hematology of Ege University Faculty of Medicine.

\section{REFERENCES}

1. Inamdar KV, Bueso-Ramos CE. Pathology of chronic lymphocytic leukemia: an update. Ann Diagn Pathol 11: 363-389, 2007.

2. Yee KW, O'Brien SM. Chronic lymphocytic leukemia: diagnosis and treatment. Mayo Clin Proc 81: 1105-1129, 2006.

3. Redaelli A, Laskin BL, Stephens JM, et al.The clinical and epidemiological burden of chronic lymphocytic leukaemia. Eur J Cancer Care (Engl) 13: 279-287, 2004.

4. Maddocks KJ, Lin TS. Update in the management of chronic lymphocytic leukemia. J Hematol Oncol 2: 29-37, 2009.

5. Rai KR, Sawitsky A, Cronkite EP, et al. Clinical staging of chronic lymphocytic leukemia. Blood 46: 219-234, 1975.

6. Binet JL, Auquier A, Dighiero G, et al. A new prognostic classification of chronic lymphocytic leukemia derived from a multivariate survival analysis. Cancer 48: 198-206, 1981.
7. Hallek M. Prognostic factors in chronic lymphocytic leukemia. Ann Oncol 19 (Suppl 4): 51-53, 2008.

8. Gribben JG. Molecular profiling in CLL. Hematology Am Soc Hematol Educ Program 2008; 444-449.

9. Meyerson M, Counter CM, Eaton EN, et al. hEST2, the putative human telomerase catalytic subunit gene, is up-regulated in tumor cells and during immortalization. Cell 90: 785-795, 1997.

10. Roos G, Krober A, Grabowski P, et al. Short telomeres are associ-ated with genetic complexity, high-risk genomic aberrations, and short surviva I in chronic lymphocytic leukemia. Blood 111: 2246-2252, 2007.

11. Brezinova J, Berkova A, Vcelikova S, et al. Telomere length, molecular cytogenetic findings, and immunophenotypic features in previously untreated patients with B-chronic lymphocytic leukemia. Neoplasma 57: 215-221, 2010.

12. Ma L, Wang J, Jiang $B$, et al. Telomere length and telomerase expression activity in mononuclear cells of patients with chronic lymphocytic leukemia. Zhongguo Shi Yan Xue Ye Xue Za Zhi 17: 1409-1412, 2009.

13. Jovanovic R, Petrusevska G, Cevrevska L, et al. Evaluation of telomerase activity in patients with chronic B lymphocytic leukemia versus age matched controls. Correlation between telomerase activity and bone marrow infiltration. Prilozi 28: 75-86, 2007.

14. Terrin L, Trentin L, Degan M, et al. Telomerase expression in B-cell chronic lymphocytic leukemia predicts survival and delineates subgroups of patients with the same IgVH mutation status and different outcome. Leukemia 21: 965-972, 2007.

15. Tchirkov A, Chaleteix C, Magnac C, et al. hTERT expression and prognosis in B-chronic lymphocytic leukemia. Ann Oncol 15: 1476-1480, 2004.

16. Verstovsek S, Giles FJ, O'Brien S, et al. Telomerase activity is not a prognostic factor in chronic lymphocytic leukemia. Leuk Res 28: 707-711, 2004.

17. Tsukasaki K, Hermine O, Bazarbachi A, et al. Definition, prognostic factors, treatment, and response criteria of adult $\mathrm{T}$-cell leukemia-lymphoma: a proposal from an international consensus meeting. J Clin Oncol 27: 453- 459, 2009.

18. Zenz T, Mertens D, Küppers R, et al. From pathogenesis to treatment of chronic lymphocytic leukemia. Nat Rev Cancer 10: 37-50, 2010

19. Zenz T, Fröhling S, Mertens D, et al. Moving from prognostic to predictive factors in chronic lymphocytic leukaemia (CLL). Best Pract Res Clin Haematol 23: 71-84, 2010.

20. Del Principe MI, Del Poeta G, Buccisano F, et al. Clinical significance of ZAP- 70 protein expression in B-cell chronic lymphocytic leukemia. Blood 108: 853-861, 2006.

21. Damle RN, Temburni S, Calissano C, et al. CD38 expression labels an activated subset within chronic lymphocytic leukemia clones enriched in proliferating B cells. Blood 110: 33523359, 2007.

22. Gentile M, Mauro FR, Guarini A, Foà R. New developments in the diagnosis, prognosis and treatment of chronic lymphocytic leukemia. Curr Opin Oncol 17: 597-604, 2005. 
International Journal of Hematology and Oncology

23. Thornton PD, Fernandez C, Giustolisi GM, et al. CD38 expression as a prognostic indicator in chronic lymphocytic leukaemia. Hematol J 5: 145-151, 2004.

24. Ibrahim S, Keating M, Do KA, et al. CD38 expression as an important prognostic factor in B-cell chronic lymphocytic leukemia. Blood 98: 181-186, 2001.

25. Damle RN, Wasil $T$, Fais $F$, et al. Ig $\vee$ gene mutation status and CD38 expression as novel prognostic indicators in chronic lymphocytic leukemia. Blood 94: 1840-1847, 1999.

26. Del Poeta G, Maurillo L, Venditti A, et al. Clinical significance of CD38 expression in chronic lymphocytic leukemia. Blood 98: 2633-2639, 2001.

27. Hus I, Kawiak J, Tabarkiewicz J, et al. ZAP-70 and CD38 expression are independent prognostic factors in patients with B-cell chronic lymphocytic leukaemia and combined analysis improves their predictive value. Folia Histochem Cytobiol 46: 147-152, 2008.

28. Moreno C, Montserrat E. New prognostic markers in chronic lymphocytic leukemia. Blood Rev 22: 211-219, 2008.

29. Hassanein NM, Perkinson KR, Alcancia F, et al. A single tube, four-color flow cytometry assay for evaluation of ZAP-70 and CD38 expression in chronic lymphocytic leukemia. Am J Clin Pathol 2010; 133:708-717, 2010.

30. Seiler T, Döhner H, Stilgenbauer S. Risk stratification in chronic lymphocytic leukemia. Semin Oncol 33: 186-194, 2006.

31. Terrin L, Trentin L, Degan M, et al. Telomerase expression in B-cell chronic lymphocytic leukemia predicts survival and delineates subgroups of patients with the same igVH mutation status and different outcome. Leukemia 21: 965-972, 2007.

32. Poncet D, Belleville A, t'kint de Roodenbeke C, et al. Changes in the expression of telomere maintenance genes suggest global telomere dysfunction in B-chronic lymphocytic leukemia. Blood 111: 2388-2391, 2008.

33. Counter CM, Gupta J, Harley CB, et al. Telomerase activity in normal leukocytes and in hematologic malignancies. Blood 85: 2315-2320, 1995.

34. Damle RN, Batliwalla FM, Ghiotto F, et al. Telomere length and telomerase activity delineate distinctive replicative features of the B-CLL subgroups defined by immunoglobulin $\mathrm{V}$ gene mutations. Blood 103: 375-382, 2004.

\section{Correspondence}

Dr. Emin KARACA

Ege Universitesi Tip Fakultesi

Tibbi Genetik Anabilim Dali

35100 Bornova, IZMIR / TURKEY

Tel: (+90.532) 2579285

Fax: (+90.232) 3903971

e-mail: karacaemin@gmail.com 